\title{
Cover plants and performance of shanks depths under corn productivity
}

\author{
Alcir José Modolo '; Jonatan Muller " ; Juan Paulo Xavier de Freitas "II \\ Lucas Dotto IV ; Rivanildo Dallacort V ; José Ricardo da Rocha Campos VI \\ Emerson Trogello VII
}

\begin{abstract}
The direct sowing system is characterized by minimum soil rotation and maintenance of vegetal residues in cover. However, incorrect management excessive traffic of machines have caused the emergence of compacted layers, which can cause decrease of crop productivity. The objective of this work was to evaluate the soil parameters and maize crop yield after management with different performance depths of fertilizer shanks, associated to the cultivation of winter coverage plants, in compacted Latosol, conducted in a direct sowing system. The experiment was carried out in two agricultural years (2013/2014 and 2014/2015), in a dystroferric Red Latosol, with a very clayey texture. The experiment was conducted in a randomized complete block design, with treatments arranged in the strip scheme, with two factors and four replications, totaling 32 experimental units. The main treatments were composed by the combination of four performance depths of fertilizer shank $(0.065,0.095,0.125$ and $0.150 \mathrm{~m}$ ) in the corn sowing process and the secondary ones by the cultivation of two winter coverage plants (black oats and turnip forage). The use of coverage plants and performance depths of the shank, among themselves, did not change the parameters of soil density and porosity, in the intercrop line. The final population of plants, seedling emergence speed index and maize production components did not vary as a result of the performance depth of the shank.
\end{abstract}

Keywords: Compacted soil; Direct sowing; Plantability; Latosol; Soil management.

\footnotetext{
' Universidade Tecnológica Federal do Paraná, Pato Branco, Brasil. alcir@utfpr.edu.br

"Instituto Federal do Rio Grande do Sul, Bento Gonçalves, Brasil. jonatan.muller@ifsc.edu.br

I"I Instituto Federal Catarinense, Rio do Sul, SC, Brasil. juanagronomia@hotmail.com

IV Universidade Tecnológica Federal do Paraná, Pato Branco, Brasil. lucas.dotto3@gmail.com

$\vee$ Universidade do Estado de Mato Grosso, Tangara da Serra, Brasil. rivanildo@unemat.br

vı Universidade Tecnológica Federal do Paraná, Pato Branco, Brasil. jricardo28@gmail.com

VIIInstituto Federal Goiano, Morrinhos, Brasil. emerson.trogello@ifgoiano.edu.br
} 


\section{INTRODUCTION}

Corn is among the major cereals grown around the world, providing products that are used for human and animal food and raw materials for the industry, mainly due to the quantity and quality of the reserves accumulated in grains (Alves et al., 2015).

Aiming at the sustainability of agricultural production areas, over time, there have been changes in cropping systems, where conventional management has gradually been replaced by the current direct sowing system (DSS), or even no-tillage, which is considered one of the main techniques of conservation management, mainly for the maintenance of soil cover with vegetal residues, species diversification through rotation, succession and/or consortia of crops, minimum rotation in the sowing line, savings in production costs and productivity increase (Almeida et al., 2018).

However, with the awakening of an intensive agriculture, in which the traffic of machines in agricultural areas is frequent and the cultivation is carried out much more respecting a temporal planning than aiming at the conservation of edaphic resources, the problem of compaction has been showing its compromising effects to the physical quality of soil and also to the development of annual crops conducted on DSS (Blanco-Canqui et al., 2018).

An alternative to try to minimize the possibility of loss of productivity caused by the increase of soil compaction is to increase soil mobilization in the sowing line by increasing performance depth of fertilizer shank, which minimizes the level of soil attribute stratification (Nunes et al., 2014).

Another option is the implantation of cover crops, which have a massive and deep root system, with characteristics that cause improvement in the structural quality of soil and at the same time, perform its decomposition (Tokura et al., 2017). However, this practice usually presents itself as an efficient alternative in the medium and long term. Thus, there is a growing demand to evaluate the practical feasibility of mechanical intervention in the minimization of Latosol compaction with very clayey 
texture, grouped with management with winter cover crops in a direct sowing system, aiming at the maintenance or even the increase of maize productivity.

The objective of this work was to evaluate soil parameters and maize crop yield after the management with different depths of the fertilizer shanks, associated with the cultivation of winter cover crops, in a compacted Latosol, conducted in direct sowing system.

\section{MATERIAL AND METHODS}

The experiment was conducted during two crop harvests (2013/2014 and 2014/2015) in a dystrophic Red Latosol (Embrapa, 2013), with a very clayey texture (76.0\% clay, $21.7 \%$ silt and $2.3 \%$ sand).

The region climate is Cfa type, subtropical humid (Alvares et al., 2013). The area is located in the southwest of Paraná state, with an average elevation of $760 \mathrm{~m}$ and a maximum slope of $3 \%$. The mean temperature, as well as the rainfall and evapotranspiration of maize crop, calculated according to Thornthwaite's (1948) methodology, during two years of the experiment, can be visualized in Figure 1A and 1B.

Figure 1 - Rainfall $(\mathrm{mm})$, evapotranspiration (Etc) and temperature $\left({ }^{\circ} \mathrm{C}\right.$ ) at the development stages of corn crop, in harvests 2013/2014 (A) and 2014/2015 (B)

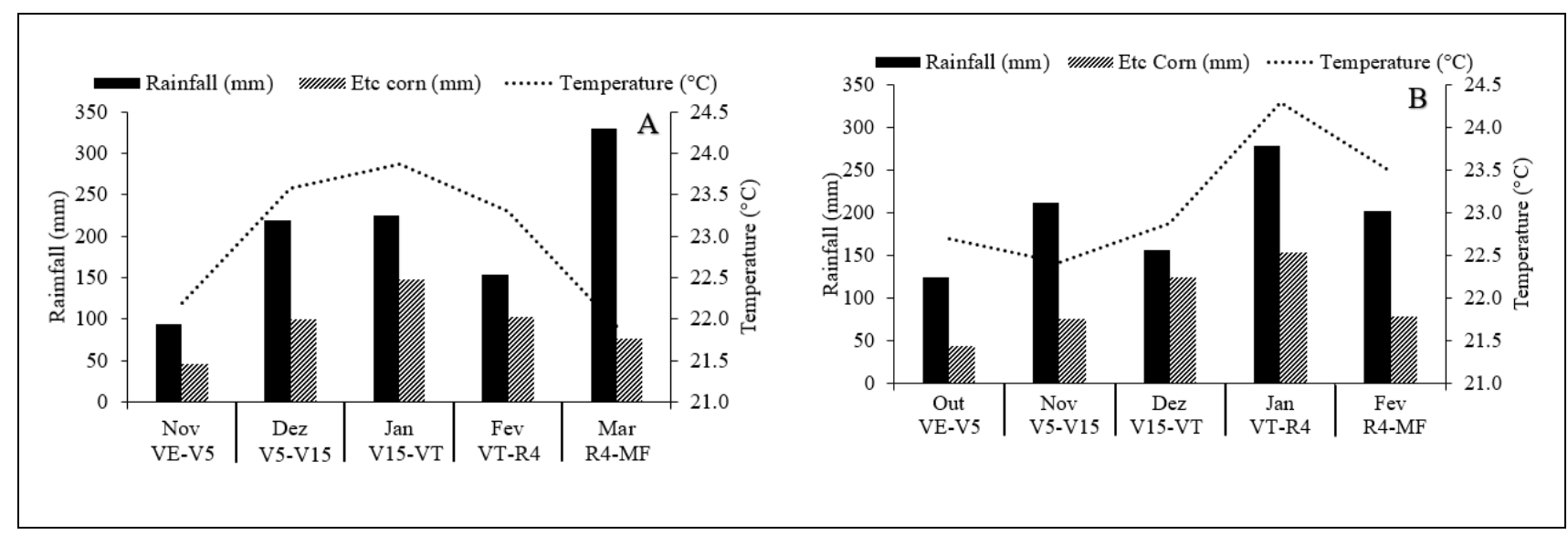

Source: Instituto Agronômico do Paraná (IAPAR). 
The experimental design adopted was a randomized block, with treatments arranged in bands scheme with two factors $(4 \times 2)$ and four replications, totaling 32 experimental units, each with $52.5 \mathrm{~m}^{2}$ (3.5 $\left.\mathrm{m} \times 15.0 \mathrm{~m}\right)$. The treatments consisted in the combination of four performance depths of shank $(0.065,0.095,0.125$ and 0.150 $\mathrm{m}$ ) in the corn sowing process, with cultivation of two winter coverage plants (black oat and forage turnip).

The chemical characterization of soil was carried out by means of random composed collection of soil, with soil tracer, in depths of $0.0-0.10$ and $0.10-0.20 \mathrm{~m}$. These were processed in the Laboratory of Soil Analysis of UTFPR and the results obtained are detailed in Table 1.

Table 1 - Soil chemical analysis at depths of 0.0-0.10 $\mathrm{m}$ and 0.10-0.20 $\mathrm{m}$

\begin{tabular}{|c|c|c|c|c|c|c|c|c|c|}
\hline Depth (m) & $\mathrm{pH} \mathrm{CaCl} 2$ & СTC & $\begin{array}{l}\text { M.O. } \\
\left(\mathrm{g} \mathrm{kg}^{-1}\right)\end{array}$ & \multicolumn{2}{|c|}{$\begin{array}{lr}P & K \\
\left(\mathrm{mg} \mathrm{dm}^{-3}\right)\end{array}$} & \multicolumn{3}{|c|}{ Al $\underset{\left(\mathrm{cmol}_{\mathrm{c}} \mathrm{dm}^{-3}\right)}{\mathrm{Ca}} \mathrm{Mg}$} & \multirow{2}{*}{$\begin{array}{c}\begin{array}{c}\mathrm{V} \\
\text { (\%) }\end{array} \\
65.3\end{array}$} \\
\hline $0.0-0.10$ & 5.5 & 15.54 & 53.0 & 21.8 & 167.0 & 0.0 & 5.9 & 3.7 & \\
\hline $0.11-0.20$ & 5.3 & 14.99 & 40.0 & 14.5 & 123.0 & 0.0 & 5.4 & 3.3 & 60.0 \\
\hline Average & 5.4 & 15.3 & 46.5 & 18.1 & 145.0 & 0.0 & 5.6 & 3.5 & 62.6 \\
\hline
\end{tabular}

Methodologies: organic matter (O.M.) by wet digestion; $\mathrm{P}, \mathrm{K}$ extracted with Mehlich-1 solution; $\mathrm{pH}$ in $\mathrm{CaCl}_{2}$ 1:2,5; exchangeable $\mathrm{Ca}, \mathrm{Mg}$ and $\mathrm{Al}$ extracted with $\mathrm{KCl} 1 \mathrm{~mol} \mathrm{~L}^{-1}$.

The Latosol compaction management was accomplished by means of two passes of the tractor tires, in the same trace, until compacting the entire area of the experiment. A New Holland ${ }^{\circledR}$ TL75E 4x2 TDA tractor (front-wheel drive) with a total load of 4,630 kg, standard $12.4 \times 24$ diagonal front tires and $18.4 \times 30$ rear tires, coupled to a sray jat Jacto, AM-12 (250 kg) 600 liters of water, totaling a mass of 5,480 kg.

After soil compaction, sowing of coverage plants was carried out, with 100 and $16 \mathrm{~kg}$ ha-1 of black oats and forage turnip, respectively. When the turnip and oat crops reached the phenological stage of full bloom and beginning of grain filling, the spraying of Glyphosate at the dose of $3.0 \mathrm{~L}$ ha-1 was carried out in order to cause 
senescence of winter crops and to allow the successive implantation of summer culture. After desiccation, the winter cover crops were managed with a straw crusher, in order to avoid packing the seedling lines when sowing the corn crop.

The corn hybrid used was Dekalb 240, with sowing density of 80,000 ha-1 seeds and line spacing of $0.7 \mathrm{~m}$. Fertilization was performed at the time of sowing with 400 kg ha-1 of the formulation (8-20-15) and a further $99 \mathrm{~kg}$ ha-1 of $\mathrm{N}$ under cover when the majority of plants reached the development stage V4 on the phenological scale.

For the crop implantation, a precision seeder-fertilizer was used, of brand Vence Tudo®, model SM 7040, with five rows, configured with a smooth cutting disc of $0.381 \mathrm{~m}$ in diameter; trencher for manure-type fertilizer with tip of 0,025 $\mathrm{m}$ wide and $22^{\circ}$ of attack angle; grout for seed deposition of doubled-disc type; controlling flat wheels depth and seed press wheel of convex type of rubber.

For total soil density and porosity, samples were collected in layers of 0.04 0.07 and 0.12 - $0.15 \mathrm{~m}$ depth, with volumetric rings $3 \mathrm{~cm}$ high and $5 \mathrm{~cm}$ in diameter. Soil density (SD) after compaction was $1.20 \mathrm{Mg} \mathrm{m}-3$, and total porosity (TP) was 0.57 m3 m-3, in the said layers. The results were obtained through the processing of samples according to the methodology described by Embrapa (2017).

Seed depth was determined at 20 days after sowing, and 30 plants were removed in each experimental unit. With the aid of a pruning shear, the corn was cut to the ground, and with a spatula the part buried in the ground was removed, measuring the length of mesocotyl to the seed.

The evaluation of final population of plants was carried out in the physiological maturation of the same, considering the existing plants in five meters of each of the three central lines of sowing, being the result extrapolated per hectare.

To determine the number of rows of grain per cob, the total number of rows of grains contained in 10 cobs, randomly collected in each experimental unit, was measured. The number of grains per row was obtained by means of the grain measurement arranged in rows of 10-grain cobs. For the number of grains per ear, the mean number of grains contained in 10 cobs was determined. 
In relation to the thousand grains weight was determined by the average of four sub-samples containing 100 grains collected in the cobs harvested randomly in the experimental units. For the final yield, all the cobs contained in the plants were harvested in 5 linear meters in the three central lines of each plot. The total grains weight was oven dried and moisture corrected to $13 \%$. Subsequently, these data were extrapolated to the area referring to one hectare.

The obtained data were submitted to analysis of variance to verify the effects of performance depth factors of shank and soil cover plants and their interaction, using the statistical program GENES (Cruz, 2013). When the F test presented a significant value $(p \leq 0.05)$ of probability, the means were compared by Tukey's test $(p \leq 0.05)$ for qualitative factors (winter cover plants). The polynomial regression test was applied for quantitative factors (performance depth of shank), with models selected by the criterion of greater R2 and significance $(p \leq 0.05)$ of the equation parameters.

\section{RESULTS AND DISCUSSIONS}

For variable soil density, it was seen that in the first year of experiment, there was a significance for performance depth of shank with the cover plant species, in 0.12 to $0.15 \mathrm{~m}$ depth layer (Table 2), but no regression model fit the observed data.

Soil density averages after application of management with cover plants and performance depths of shank were 1.07 and $1.09 \mathrm{Mg} \mathrm{m}^{-3}$, in the $0.04-0.07 \mathrm{~m}$ depth layer, in the first and second year of experiment, respectively. In the $0.12-0.15 \mathrm{~m}$ layer, the average density was similar in the first and second year of experiment (1.15 $\left.\mathrm{Mg} \mathrm{m}^{-3}\right)$.

According to Klein (2012) the density in cultivable soils varies depending on the texture and organic matter content. In general the critical values for root development are 0.9 to $1.8 \mathrm{Mg} \mathrm{m}^{-3}$. In general, after growing coverage plants, the soil density appeared to be below the level considered as restrictive to maize crop development, since Derpsch et al. (1991) developed a survey in the period 1977 and 1984 on soil 
cover and preparation systems, in a very clayey Latosol, assert that apparent densities of less than $1.20 \mathrm{Mg} \mathrm{m}^{-3}$ probably do not cause rooting crop problems or aeration.

Table 2 - Sources of variation (SV), degrees of freedom (DF) and mean squared of density soil parameters (SD) and total porosity (TP), at two sampling depths (0.04 $0.07 \mathrm{~m}$ ) and (0.12 - $0.15 \mathrm{~m})$, in harvests 2013/2014 and 2014/2015, due to shank performance depth (Dep.) and soil cover plants (Cov.)

\begin{tabular}{|c|c|c|c|c|c|}
\hline \multirow{3}{*}{ SV } & \multirow{3}{*}{ DF } & \multicolumn{4}{|c|}{ Crop 2013/2014 } \\
\hline & & SD & TP & SD & TP \\
\hline & & \multicolumn{2}{|c|}{$0.04-0.07(\mathrm{~m})$} & \multicolumn{2}{|c|}{$0.12-0.15(\mathrm{~m})$} \\
\hline Block & 3 & 0.0043 & 0.0004 & 0.0014 & 0.0016 \\
\hline Dep. & 3 & 0.0050 & 0.0011 & $0.0040 *$ & 0.0004 \\
\hline Error (a) & 9 & 0.0013 & 0.0005 & 0.0005 & 0.0003 \\
\hline Cov. & 1 & 0.0006 & 0.0007 & 0.0006 & 0.0002 \\
\hline Error (b) & 3 & 0.0004 & 0.0004 & 0.0029 & 0.0009 \\
\hline Dep x Cov & 3 & 0.0011 & 0.0005 & $0.0029 *$ & 0.0028 \\
\hline Residue & 9 & 0.0019 & 0.0008 & 0.0004 & 0.0008 \\
\hline Average & & 1.0723 & 0.6378 & 1.1536 & 0.6083 \\
\hline \multirow[t]{2}{*}{ CVe (\%) } & & 4.08 & 4.50 & 1.78 & 4.59 \\
\hline & & & & \multicolumn{2}{|c|}{ Crop 2014/2015 } \\
\hline Block & 3 & 0.0031 & $0.0 \overline{003}$ & 0.0015 & 0.0007 \\
\hline Dep. & 3 & 0.0031 & 0.0011 & 0.0027 & 0.0009 \\
\hline Error (a) & 9 & 0.0033 & 0.0017 & 0.0018 & 0.0007 \\
\hline Cov. & 1 & 0.0001 & 0.0000 & 0.0003 & 0.0004 \\
\hline Error (b) & 3 & 0.0003 & 0.0022 & 0.0025 & 0.0004 \\
\hline Dep x Cov & 3 & 0.0011 & 0.0029 & 0.0018 & 0.0006 \\
\hline Residue & 9 & 0.0014 & 0.0023 & 0.0024 & 0.0003 \\
\hline Average & & 1.0993 & 0.6312 & 1.1584 & 0.6137 \\
\hline CVe (\%) & & 3.39 & 7.62 & 4.24 & 2.82 \\
\hline
\end{tabular}

*: Significant $(\mathrm{P} \leq 0.05)$. CVe: coefficient of residual variation.

It is possible to affirm that black oats and forage turnip during their development do not have, among themselves, different capacity to change soil density after the compaction generated by machine traffic. This statement supports the research developed by Mazurana et al. (2013) which verified that there was no change in soil density, independently of the evaluated layer, as a function of the soil cover condition (fallow and oats + vetch). Similar results were obtained by Silveira Junior et al. (2012), which analyzed the physical quality of a Red Latosol under no-tillage went to mechanical 
decomposition (scarification) and biological decomposition (forage turnip), verified that the soil physical attributes were not altered by the use of coverage plants.

Likewise, the variation in performance depth of the shank was not able to change the soil density in the evaluated layers. However, it is important to point out that the soil density samples were collected between the sowing lines of the corn crop. Nunes et al. (2014) affirm that sowers equipped with shanks have limited soil mobilization capacity, being restricted to the sowing line, thus not influencing the soil density in the interline.

For the total porosity (TP) parameter there was no significance in any of the treatments (Table 2). The mean TP value in the layer was $0.04-0.07 \mathrm{~m}$ in the two years of evaluation was de $0.63 \mathrm{~cm}^{3} \mathrm{~cm}^{-3}$, and for the layers of $0.12-0.15 \mathrm{~m}$, in the two crops, TP was $0.61 \mathrm{~cm}^{3} \mathrm{~cm}^{-3}$. Silva et al. (2011) obtained similar results when evaluating the contribution of phytomass by succession of cover crops and their influence on soil physical attributes in no-tillage. The authors found that total porosity values increased in the superficial layer as a function of cover crop, concluding that no-tillage system with continuous straw contribution minimizes soil compaction.

The sowing depth was not significant for the interaction of the factors tested, however, the performance depth of shank and the types of cover plants influenced the same isolated form (Table 3).

Table 3 - Sources of variation (SV), degrees of freedom (DF) and mean square of depth of sowing character (PS), in harvests 2013/2014 and 2014/2015, as a function of performance depth of shank (Dep.) and soil cover plants (Cov.)

\begin{tabular}{lccc}
\hline SV & DF & \multicolumn{2}{c}{ Crop } \\
\hline Block & 3 & 0.008 & $\mathbf{2 0 1 4 / 2 0 1 5}$ \\
Dep. & 3 & $1.406^{\star}$ & 0.121 \\
Error (a) & 9 & 0.339 & $1.123^{*}$ \\
Cov. & 1 & $0.291^{\star}$ & 0.152 \\
Error (b) & 3 & 0.011 & 0.080 \\
Dep x Cov & 3 & 0.296 & 0.158 \\
Residue & 9 & 0.507 & 0.011 \\
Average & & 5.487 & 0.155 \\
\hline CVe (\%) & & 12.97 & 5.850 \\
\hline
\end{tabular}

*: Significant $(P \leq 0.05)$. CVe: coefficient of residual variation. 
In relation to coverage plants, black oats was found to have a $3.6 \%$ higher sowing depth in relation to the forage turnip crop in 2013/2014 harvest, with mean values close to $0.055 \mathrm{~m}$ in both treatments (Table 4).

Table 4 - Corn sowing depth $(\mathrm{m})$ as a function of soil coverage plants, in harvests 2013/2014

\begin{tabular}{lc}
\hline Treatments & $\begin{array}{c}\text { Sowing Depth (m) } \\
\text { Crop 2013/2014 }\end{array}$ \\
\hline Black oat & $0.056 \mathrm{a}$ \\
Forage turnip & $0.054 \mathrm{~b}$ \\
\hline Average & 0.0548 \\
\hline
\end{tabular}

Averages followed by different lowercase letters in the column differ by Tukey test $(P \leq 0.05)$.

Regarding the performance depth of shank, in the first year of experiment there was no adjustment of the regression model, presenting an average value of $0.055 \mathrm{~m}$. In harvest of $2014 / 2015$, it is noted that every $0.01 \mathrm{~m}$ increase in performance depth of fertilizer shank occurs an increase of $0.0009 \mathrm{~m}$ in the depth of corn seed deposition. This result is likely to be associated with higher soil mobilization generated by shank deepening, since a larger volume of soil upturned in the sowing line tends to generate lower support of the seedling depth limiting wheels (Figure 2).

Figure 2 - Corn sowing depth $(\mathrm{cm})$ as a function of performance depths of fertilizer shank in harvest of 2014/2015: Significant $(P \leq 0.05)$

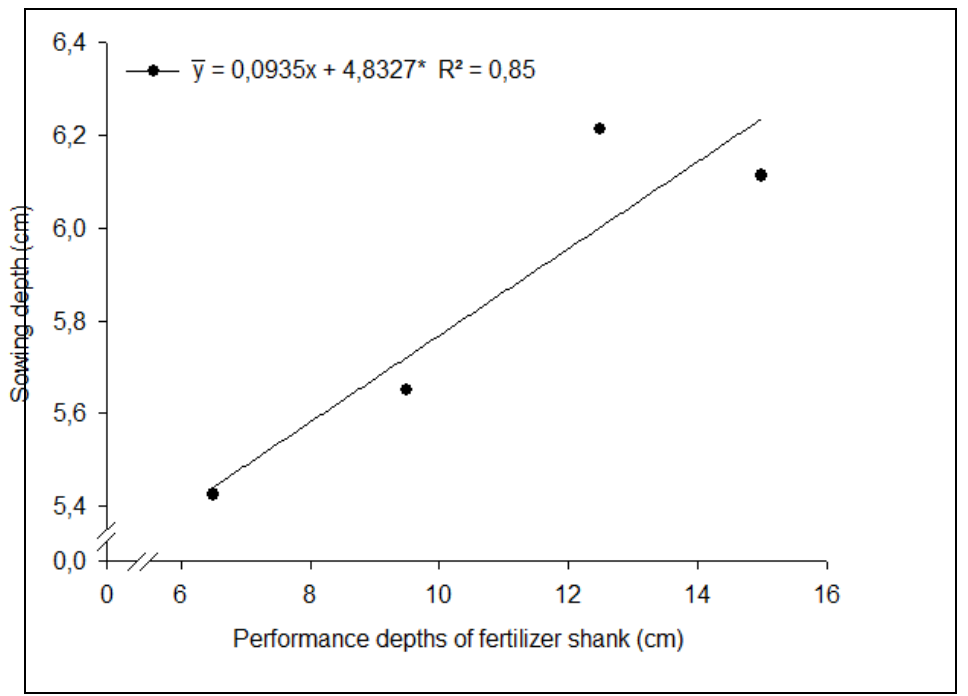


The sowing depth is a limiting factor that will influence the performance of the crop, since if the seed is improperly deposited in the soil, the limitation of plant development may occur in later stages of growth due to the conditions of temperature, light and humidity (Gazola et al., 2014). Fattahi et al. (2015) evaluating different sowing depths in the corn crop, is recommended that in order to have a good development and growth of the root system, corn seeds should be sown around $0.05 \mathrm{~m}$ of soil depth.

Among the essential factors for seed germination is the moisture content and soil temperature. In this regard, Silva et al. (2015) analyzing the emergence of corn plants according to sowing depth (0.02 to $0.08 \mathrm{~m}$ ), in clayey Nitosol, it was found a higher emergence speed and total emergence of plants at seeding depths of 0.06 and $0.08 \mathrm{~m}$. The authors state that these results were probably favored by the higher water content in the soil, in that layer.

It is also known that greater depths of sowing, can cause fall in productivity of the corn crop, in a period without rainfall. Koakoski et al. (2007) affirm that the greater the deposition depth, the greater the energy consumption in emergency, besides damages caused by low temperatures and low oxygen levels, even the seeds being susceptible to attack by pathogens and pests and also by surface sealing.

The performance depth of shank significantly influenced the final population of plants (Table 5), but there was no adjustment of the data to the regression models tested. It is also noted that the averages presented for the 2013/14 and 2014/15 crops were 71,430 and 74,710 plants ha-1, respectively. Similar results were obtained by Bertonha et al. (2015) when analyzing 5 performance depths of shanks and three attack angles, in Red Latosol with $47 \%$ of clay. The authors found that even though there was greater soil mobilization due to the greater performance depth of shanks, the final population of plants remained with approximately 70,000 plants ha-1.

The number of grain rows per ear (NRE) did not present significance as a function of the performance depth of shanks and cover plants, with a mean value of 15.18 and 14.25 in the 2013/14 and 2014/15 harvests, respectively. Analyzing the agronomic characteristics of three corn crops conducted in direct sowing and 
minimum tillage, Bertolini et al. (2008) did not verify NRE variation as a function of soil management treatments, and the values oscillated between 13,84 and 14.78.

Table 5 - Sources of variation (SV), degrees of freedom (DF) and mean square of the characters final population of plants (PF), number of grains rows per ear (NRE), number of grains per row (NGR), number of grains per ear (NGE), a thousand grains weight (TGW) and corn yield (CY), in harvests 2013/2014 and 2014/2015, as a function of the performance depth of shanks (Dep.) and soil cover plants (Cov.)

\begin{tabular}{lccccccc}
\hline \multirow{2}{*}{ SV } & DF & PF & NRE & NGR & NGE & TGW & CY \\
\hline Block & 3 & 34.58 & 0.138 & 1.30 & 591.70 & 195.79 & 1.243 \\
Dep. & 3 & $35.77^{*}$ & 0.355 & 1.61 & 644.35 & 1989.08 & 3.544 \\
Error (a) & 9 & 7.42 & 0.272 & 1.93 & 863.48 & 1088.98 & 2.128 \\
Cov. & 1 & 30.77 & 0.003 & 1.40 & 284.05 & 145.78 & 2.787 \\
Error (b) & 3 & 30.85 & 0.459 & 5.93 & 2449.85 & 768.84 & 1.692 \\
Dep x Cov & 3 & 9.34 & 0.050 & 1.64 & 340.98 & 208.35 & 1.187 \\
Residue & 9 & 8.83 & 0.439 & 2.35 & 1110.36 & 732.43 & 1.653 \\
Average & & 71.43 & 15.185 & 32.07 & 487.15 & 316.70 & 10.577 \\
\hline CVe (\%) & & 4.16 & 4.36 & 4.78 & 6.84 & 8.55 & 12.16 \\
\hline & & & Crop 2014/2015 & & \\
Block & 3 & 24.33 & 0.010 & 0.082 & 61.81 & 460.00 & 1.367 \\
Dep. & 3 & $86.77^{*}$ & 0.050 & $4.191 *$ & 793.28 & $830.00 *$ & $14.846^{*}$ \\
Error (a) & 9 & 16.58 & 0.207 & 0.927 & 253.41 & 150.00 & 1.195 \\
Cov. & 1 & 3.37 & 0.020 & 3.906 & $1172.01 *$ & 1080.00 & 1.754 \\
Error (b) & 3 & 5.92 & 0.043 & 0.359 & 51.89 & 360.00 & 0.283 \\
Dep x Cov & 3 & 6.54 & 0.323 & 0.787 & 1031.85 & 29.00 & $3.276^{*}$ \\
Residue & 9 & 15.92 & 0.289 & 0.947 & 768.68 & 210.00 & 0.597 \\
Average & & 74.71 & 14.250 & 38.138 & 543.47 & 360.38 & 10.293 \\
\hline CVe(\%) & & 5.34 & 3.77 & 2.55 & 5.10 & 4.03 & 7.51 \\
\hline
\end{tabular}

*: Significant $(P \leq 0.05)$. CVe: coefficient of residual variation.

In the 2013/14 crop, the number of grains per row (NGR) did not show significant variation as a function of the coverage plants and shanks, with an average of 32.07. In the $2014 / 15$ harvest, the NGR was significant only for the performance depth of shanks, however, there was no adjustment of regression model to the observed data set, presenting an average value of 38.13 grains per row. Such data supports those obtained by Lazaro et al. (2013), which evaluated the yield components of corn in succession to the cultivation of green manures, did not obtain a significant difference in NGR data. 
This NGR result is not significant due to the application of treatments, probably due to the fact that soil presents high levels of macronutrients and organic matter. In addition, rainfall was superior to crop evapotranspiration throughout the corn development cycle, which may suppress a possible positive effect of treatments on this parameter (Figure 1A and 1B). Cherubin et al. (2014) analyzing the crop agronomic performance in succession to soil cover species conducted in direct sowing verified that NGR when cultivated on forage turnip, ryegrass and black oat residues did not differ among them.

In harvest of 2013/14, the variable number of grains per ear (NGE) showed no significant difference for any of the treatments, with a mean of 487.15. Already, in harvest of 2014/1, the management with winter cover crops caused a significant result, in which NGE was higher when corn was cultivated in the area with black oat residues (Table 6).

Table 6 - Number of grains per ear (NGE) as a function of the soil coverage plants, in harvest of $2014 / 2015$

\begin{tabular}{cc}
\hline Treatments & $\begin{array}{c}\text { Number of grains per ear } \\
\text { Crop 2014/2015 }\end{array}$ \\
\hline Black oat & $549,52 \mathrm{a}$ \\
Forage turnip & $537,42 \mathrm{~b}$ \\
\hline Average & 543,47 \\
\hline
\end{tabular}

Averages followed by different lowercase letters in the column differ by Tukey test $(P \leq 0.05)$.

The higher NGE obtained in black oat succession compared to forage turnip may be associated with corn crop being sown 37 days after desiccation of winter crops, allowing better synchronization in the use of $\mathrm{N}$ released by the culture of black oats in relation to the turnip forage. Crusciol et al. (2008) evaluating the release of macronutrients from the black oat straw verified that after 35 days of oat desiccation, more than $45 \mathrm{~kg}$ of $\mathrm{N}(64 \%)$ had already been released, and the crop had an average yield of 2,953 $\mathrm{kg} \mathrm{ha}^{-1}$ of dry matter, without application of basic fertilization.

With regard to the variable thousand grains weight (TGW) in harvest of 2013/14, it did not respond significantly to the treatments with plants of soil cover and 
performance depths of shank, presenting average value of 316,70 g. On the other hand, in harvest of 2014/15 TGW presented a significant result for the performance depths of fertilizer shank, but no significant adjustment was observed for any regression model tested, with a mean value of $360.38 \mathrm{~g}$. These results corroborate with those presented by Conte et al. (2009), where working with corn yield at two performance depths of shank (0.06 and $0.12 \mathrm{~m}$ ) were also not significant for corn productivity.

Forte et al. (2018) working with soil cover crops in agricultural crops describe that corn grown in the area after winter coverings with turnip + vetch in the direct sowing system are higher in relation to conventional tillage management, the same authors still mention that corn TGW yield component, resulted in an increased final productivity.

For corn yields (CY) only in the second year, there was significance for the interaction between the factors tested, however, no regression model was fitted to the data, with an average of 10,293 kg ha-1. Debiasi et al. (2010) analyzing the yield of soybeans and corn after winter cover and mechanical decompression of soil, found that the cultivation of black oat and forage turnip, in relation to the fallow, provided higher productivity of crops in dry season. The authors also found that the different performance depths of fertilizer shank ( 0.06 and $0.12 \mathrm{~m}$ ) did not cause a change in corn productivity during the two years of evaluation. Similar results were found by Tricai et al. (2016) evaluating that corn yield in terms of three performance depths of shanks (12:09; 12:11 and 12:15 m) found no significant difference in Latosol with $48 \%$ clay.

Seki et al. (2015) studying the effect of decomposition practices in Nitosol (60\% of clay) by means of subsoiling at $0.40 ; 0.30$ and $0.20 \mathrm{~m}$ depth, before winter and summer crop sowing, and by crop no-tillage with rod-like and double-disc grooving mechanism, did not observe any change in the development and productivity of corn crop.

It is assumed that failure to obtain significant productivity results as a function of management with different performance depths of shanks may be associated with high macronutrient and organic matter content available in the soil, as well as regular rainfall and in amount higher than the crop evapotranspiration occurred during the whole development period of corn crop, in the two years of experiment (Figures 2A e 2B). 


\section{CONCLUSIONS}

The use of coverage plants and performance depths of shanks were not effective in modifying the parameters of soil density and porosity in the intercrop line.

In general, the final population of plants and crop production components did not vary according to the performance depths of shank. For soil coverage factor, only in the second year of cultivation was possible to note the increase for the number of grains per ear with the use of forage turnip.

\section{ACKNOWLEDGEMENTS}

To CNPq (Research Productivity) e Fundação Araucária for the financial support.

\section{REFERENCES}

ALMEIDA V, ALVES JÚNIOR J, MESQUITA M, EVANGELISTA AWP, CASAROLI D, BARRISTI R. Comparação da viabilidade econômica da agricultura irrigada por pivô central em sistemas de plantios convencional e direto com soja, milho e tomate industrial. Glob. Scie. Tec. 2018;11(2):256-273. Avaiable from:

https://rv.ifgoiano.edu.br/periodicos/index.php/gst/article/view/1014/609.

ALVARES CA, STAPE JL, SENTELHAS PC, GONÇALVES JLM, SPAROVEK G. Köppen's climate classification map for Brazil. Meteo. Zeit. 2013; 22 (6): 711-728. Avaiable from: http://dx.doi.org/10.1127/0941-2948/2013/0507.

ALVES BM, CARGNELUTTI FILHO A, BURIN C, TOEBE M, SILVA LP. Divergência genética de milho transgênico em relação à produtividade de grãos e da qualidade nutricional. Ciênc. Rur. 2015; 45 (5): 884-891. Avaiable from: http://dx.doi.org/10.1590/01038478 cr20140471.

BERTOLINI EV, GAMERO CA, SALATA AC, PIFFER, CR. Antecipação da adubação de semeadura do milho em dois sistemas de manejo do solo. Rev. Bras. Ciênc. Solo. 2008; 32 (6): 2355-2366. Avaiable from: http://dx.doi.org/10.1590/S010006832008000600014 .

BERTONHA RS, FURLANI CEA, SILVA VFA, WRIGHT DL. Tractor performance and corn crop development as a function of furrow opener and working depth in a Red Latosol. Aus. Jour. Crop Scie. 2015; 9 (9): 812-818. Avaiable from: http://hdl.handle.net/11449/172148. 
BLANCO-CANQUI H, RUIS SJ No-tillage and soil physical environment. Geoderma. 2018; 326 (1): 164-200. Avaiable from: http://dx.doi.org/10.1016/j.geoderma. 2018.03.011.

CHERUBIN MR, FABBRIS C, WEIRICH SW, ROCHA EMT, BASSO CJ, SANTI AL, LAMEGO FP. Desempenho agronômico do milho em sucessão a espécies de cobertura do solo sob sistema plantio direto no sul do Brasil. Glo. Scie. 2014; 7 (1): 76-85. Avaiable from: http://dx.doi.org/10.14688/1984-3801/gst.v7n1p76-85.

CONTE O, LEVIEN R, TREIN CR, DEBIASI H, MAZURANA M. Rendimento do milho em diferentes condições físicas de solo e quantidade de resíduo na ausência ou na presença de irrigação. Ciênc. Rur. 2009; 39 (4): 1069-1076. Avaiable from: http://dx.doi.org/10.1590/S0103-84782009005000022.

CRUSCIOL CAC, MORO E, LIMA EV, ANDREOTTI M. Taxas de decomposição e de liberação de macronutrientes da palhada de aveia preta em plantio direto. Bragantia. 2008; 67 (2): 261-266. Available from: http://dx.doi.org/10.1590/S000687052008000200024 .

CRUZ CD. Genes: a software package for analysis in experimental statistics and quantitative genetics. Act. Scie. Agr. 2013; 35 (3): 271-276. Avaiable from: http://dx.doi.org/10.4025/actasciagron.v35i3.21251.

DEBIASI H, LEVIEN R, TREIN CR, CONTE O, KAMIMURA KM. Produtividade de soja e milho após coberturas de inverno e descompactação mecânica do solo. Pesq. Agrop. Bras. 2010; 45 (6): 603-612. Avaiable from: http://dx.doi.org/10.1590/S0100204X2010000600010.

DERPSCH R, ROTH CH, SIDIRAS N, KÖPKE U. Controle de erosão no Paraná, Brasil: sistemas de cobertura do solo, plantio direto e preparo conservacionista do solo. Eschborn, Germany-Londrina; 1991.

EMBRAPA (EMPRESA BRASILEIRA DE PESQUISA AGROPECUÁRIA). Manual de métodos de análise de solo. 3. ed. Brasília-DF; 2017. Avaiable from:

https://www.embrapa.br/en/busca-de-publicacoes/-/publicacao/1085209/manual-demetodos-de-analise-de-solo.

EMBRAPA (EMPRESA BRASILEIRA DE PESQUISA AGROPECUÁRIA). Sistema brasileiro de classificação de solos. 3. ed. Brasília-DF; 2013.

FATTAHI SH, KHODAEI M, NAVID H. Evaluation of corn planter under travel speed, working depth, pressure wheel and cone index. Agric. Eng. Int. 2015; 17 (4): 73-80. Avaiable from: https://cigrjournal.org/index.php/Ejounral/article/view/3364/2224. 
FORTE CT, GALON L, BEUTLER AN, PERIN GF, PAULETTI ESS, BASSO FJM, HOLZ CM, SANTIN CO. Coberturas vegetais do solo e manejo de cultivo e suas contribuições para as culturas agrícolas. Rev Bras. Ciên. Agrár. 2018; 13 (1): 1-10. Avaiable from: http://dx.doi.org/10.5039/agraria.v13i1a5504.

GAZOLA D, ZUCARELI C, CAMARGO MC. Comportamento germinativo de sementes de cultivares de milho sob condições de hipóxia. Científica. 2014; 42 (3): 224-232. Avaiable from: http://dx.doi.org/10.15361/1984-5529.2014v42n3p224-232.

KOAKOSI A, SOUZA CMA, RAFULL LZL, SOUZA LCF, REIS EF. (2007) Desempenho de semeadora-adubadora utilizando-se dois mecanismos rompedores e três pressões da roda compactadora. Pesq. Agropec. Bras. 42: 757-731. Avaiable from: http://dx.doi.org/10.1590/S0100-204X2007000500016.

KLEIN VA. Física do solo. 2 ed. Passo Fundo: Ed. Universidade de Passo Fundo; 2012. LÁZARO RL, COSTA ACT, SILVA KF, SARTO MVM, DUARTE JÚNIOR JB. Produtividade de milho cultivado em sucessão à adubação verde. Pesq. Agropec. Trop. 2013; 43 (1): 1017. Avaiable from: http://dx.doi.org/10.1590/S1983-40632013000100008.

MAZURANA M, FINKJR, SILVEIRA VH, LEVIEN R, ZULPO L, BREZOLIN D. Propriedades físicas do solo e crescimento de raízes de milho em um argissolo vermelho sob tráfego controlado de máquinas. Rev. Bras. de Ciên. do Solo. 2013; 37 (5): 1185-1195. Avaiable from: http://dx.doi.org/10.1590/S0100-06832013000500008.

NUNES MR, DENARDIN JE, FAGANELLO A, PAULETTO EA, PINTO LFS. Efeito de semeadora com haste sulcadora para ação profunda em solo manejado com plantio direto. Rev. Bras. de Ciên. do Solo. 2014; 38 (2): 627-638. Avaiable from: http://dx.doi.org/10.1590/S0100-06832014000200027.

SEKI AS, SEKI FG, JASPER SP, SILVA PRA, BENEZ SH. Effects of soil decompaction techniques in an area under a system of direct seeding. Rev. Ciên. Agron. 2015; 46 (3): 460-468. Avaiable from: http://dx.doi.org/10.5935/1806-6690.20150027

SILVA, SOUZA LCF, VITORINO ACT, GONÇALVES MC. Aporte de fitomassa pelas sucessões de culturas e sua influência em atributos físicos do solo no sistema plantio direto. Bragantia. 2011; 70 (1): 147-156. Avaiable from: http://dx.doi.org/10.1590/S0006-87052011000100021.

SILVA PRA, DIAS PP, CORREIA TPS, SOUSA SFG. Emergência de plântulas de milho em diferentes profundidades de semeadura. Irriga, 2015; 1 (1): 178-185. Avaiable from: http://dx.doi.org/10.15809/irriga.2015v1n1p178.

SILVEIRA JÚNIOR SD, SILVA AP, FIGUEIREDO GC, TORMENA CA, GIAROLA NFB. Qualidade física de um Latossolo Vermelho sob plantio direto submetido à descompactação mecânica e biológica. Rev. Bras. de Ciên. do Solo. 2012; 36 (6): 18541867. Avaiable from: http://dx.doi.org/10.1590/S0100-06832012000600020. 
THORNTHWAITE CW. An approach toward a rational classification of climate. Geogr. Review. 1948; 38 (1): 55-94. Avaiable from: http://dx.doi.org/10.2307/210739.

TOKURA LK, SECCO D, ZANÃO JÚNIOR LA, SIQUEIRA JAC, SANTOS RF, MARTINS MFL, ALOVISI AMT, OLIVEIRA LC, HOJO RH, PEREIRA N, PILATTI MA, MOREIRA MCDL, VILLA B, SCHMATZ MJ. Structuring potential of some cover crops and crambe in Haplortox under no-tillage system. Afric. Jour. of Agricul. Resear. 2017; 12 (24): 2078-2086. Avaiable from: http://dx.doi.org/10.5897/AJAR2016.11725.

TRICAI E, FURLANI CEA, BERTONHA RS, SILVA VFA, COMPAGNON AM, CASSIA MT. Energy demand of furrow openers and corn yield according to the soil disturbance in no till system. Afric. Jour. of Agricul. Resea. 2016; 11 (17): 1538-1542.

http://dx.doi.org/10.5897/AJAR2015.8789. 